\title{
Tanulmányok
}

\section{A MEGÚJULÓ ENERGIA TERMELÉSÉNEK HATÁSA A MAGYARORSZÁGI SZÉNBÁNYÁSZAT HELYZETÉRE}

\section{THE EFFECT OF THE RENEWABLE ENERGY PRODUCTION ON THE HUNGARIAN COAL MINING STATUS}

\author{
Herczeg András ${ }^{1}$, Tóth Máté2 ${ }^{2}$ Vastag Gyula ${ }^{3}$ \\ ${ }^{1}$ doktorjelölt, Budapesti Corvinus Egyetem Gazdaságinformatika Doktori Iskola, Budapest \\ andras.herczeg@uni-corvinus.hu \\ 22doktorjelölt, Széchenyi István Egyetem Regionális- és Gazdaságtudományi Doktori Iskola, Győr \\ mate.toth@ratkynet.hu \\ 3 az MTA doktora, egyetemi tanár, Budapesti Corvinus Egyetem, Budapest \\ gyula.vastag@uni-corvinus.hu
}

\begin{abstract}
ÖSSZEFOGLALÁS
A magyar szénipar jövőképe az elmúlt években jelentősen átalakult. A szénalapú villamosenergia-termelés csökkenését a gazdasági környezet mellett a változó energiapolitikai (elsősorban szigorodó környezetvédelmi) megfontolások vezérlik. Jogi-szabályozási oldalról a szénipar helyzetét komplex rendszerként ajánljuk értelmezni, ahol az affirmatív (támogató) és a megszorító hatások kölcsönhatásában a megszorító felé mozdult el az egyensúly a szénipari szerkezetátalakítási támogatás, a Paks II kiemelt projekt és a megújulók helyzetét vizsgálva. Mindezt azok a jogtechnikai megoldások teszik érdekessé, amelyek a szénfillér nyújtásának jogi keretét nem szüntették meg, csak az összegét vették le nullára, tisztázzák a szénfillér és a C-tarifa közjogi státuszát (bíróság által), és végül a C-tarifa adómentességet indirekt módon vezetik ki a jogrendszerből. Mindezek a komplex rendszer elemeit formai, jogi-normatív oldalról változatlanul hagyják, tartalmilag azonban érvényesítve a hangsúlyeltolódást.
\end{abstract}

\section{ABSTRACT}

The vision of the Hungarian coal industry has changed significantly in recent years. The decline in coal-based electricity generation is driven by both the economic environment and the changing energy policy (primarily environmental) considerations. From a regulatory point of view, we recommend interpreting the situation of the coal industry as a complex system, where the indirect interaction of affirmatory and restrictive effects are to be considered together but where the balance has shifted towards the latter. In this sense, the coal subsidy (the 'szénfillér') was not abolished but deducted to zero whilst the clarification of the coal subsidies and C tariff status (declared public law nature and the indirect abolishment of tax exemption) demonstrate the enforced shift in emphasis substantively. 
Kulcsszavak: energiamix, megújuló energia, szénbányászat

Keywords: energy mix, renewable energy, coal mining

Az országok fejlettségéhez és gazdasági teljesítményéhez szorosan kapcsolódik energiafelhasználásuk nagysága és összetétele (EC, 2014; Nielsen et al., 2018), így a nyersanyagokhoz való hozzáférés mellett a technológiai fejlődés és a jogi-szabályozói környezet is dinamikusan alakítja az energiamixet (Haftendorn et al., 2012). A 2011-ben elfogadott nemzeti energiastratégia (NFM, 2011) még a nukleáris-, szén- és megújuló alapú villamosenergia-termelést helyezte előtérbe Magyarországon. Azonban a szénipar helyzetét jogi-szabályozási oldalról megvizsgálva egy olyan komplex rendszer azonosítható, amelyben a támogató és a megszorító hatások közvetett kölcsönhatásban állnak. Az 1772/2018. (XII. 21.) Korm. határozat alapján kidolgozás alatt álló új nemzeti energiastratégia (NES) várhatóan a szénbányászat további visszaszorulását erősíti.

\section{HELYZETKÉP: \\ A SZÉNBÁNYÁSZAT JELENTŐSÉGÉNEK CSÖKKENÉSE}

A fenntarthatósági követelmények (kiemelten az üvegházhatású gázok kibocsátása csökkentésének szándéka) következtében a hagyományos fosszilis tüzelőanyagok részesedése mérséklődik a teljes energiafelhasználáson belül. Felhasznált mennyiségük azonban tovább emelkedik, elsősorban a globális gazdasági növekedés miatt folyamatosan növekvő energiafelhasználás következtében (Miller, 2017). Ez utóbbi tendencia alól a szén jelentette a kivételt: a 2010-es évek közepére a globális primer energiafelhasználáson belül a szénfelhasználás növekedése lelassult, majd csökkenésnek indult (IEA, 2018). A fejlett gazdaságok szénfelhasználása pedig még nagyfokú politikai támogatás esetén is csökken. Erre a legjobb példa az Amerikai Egyesült Államok (USA), ahol a belföldi szénfelhasználás 2016-ról 2017-re 1,9\%-kal csökkent, miközben az amerikai szénkitermelés (+6,4\%-kal) és az amerikai szénbányák által alkalmazott munkavállalók száma is nőtt az időszakban (EIA U.S., 2018). Azonban a foglalkoztatottak számának növekedése is csak átmenetinek tekinthetö, mivel az ágazatban dolgozók növekvő létszáma érezhető termelékenységcsökkenést eredményezett, negatívan érintve a munkáltatók profitabilitását.

A szénfelhasználás aránya várhatóan tovább fog csökkenni az energiamixben (Herczeg-Tóth, 2019):

- A szénigény alapvetően a villamosenergia-szektortól függ (az USA-ban a 2017. évi szénfelhasználás 92,8\%-át a villamosenergia-termelés tette ki). 
A megújuló energiára vonatkozó előírások (EU 20-20-20-as célok ${ }^{1}$, az USA államaiban az ún. RPS-elöírások ${ }^{2}$ ) közvetlenül biztosítják a megújuló energiaforrásokra fókuszáló hosszú távú kormányzati támogatást, ami közvetetten a szénalapú energiatermelés további csökkenésével jár az energiamixen belül.

- A folyamatos innováció következtében a helyettesítő tüzelőanyag-típusok (palagáz-forradalom), illetve az alternatív (elsősorban megújuló) technológiák jövedelmezőbbé válnak.

- A környezetvédelmi és klímapolitikai elvárások miatt a piaci szereplök a szenes technológiákat egyre inkább kedvezőtlen választásnak tekintik árazási $\left(\mathrm{CO}_{2}\right.$-kvóták árának emelkedése) és marketing („dirty coal”) szempontból is.

\section{A MAGYARORSZÁGI SZÉNBÁNYÁSZAT HELYZETE AZ EURÓPAI ENERGIAPIACI FOLYAMATOK TÜKRÉBEN}

Az Európai Unió (EU) tagállamainak energiamixén belül a fosszilis energiahordozók aránya visszaszorul a megújuló energiára vonatkozó célok teljesítése következtében (Eurostat, 2019). Németország esetében az atomerőmüvek leállítása, valamint a megújuló energia kinyerésére irányuló nagymértékủ fejlesztések (Energiewende) sem vezettek a fosszilis energiahordozók felhasználásának növekedéséhez. Azonban az is tény, hogy a német szénalapú termelés csökkentése lassú ütemben halad, illetve az időjárásfüggő megújulók egy napon belüli kiegyensúlyozási igénye okozhatja a szén- és más fosszilis erőmüvek kiugróan magas kihasználását.

A szénfogyasztás mérséklődése a magyarországi energiapiacra is érvényes. A szénalapú villamosenergia-termelést folytató Vértesi Erőmű (VÉRT) villamosenergia-termelése 2015-ben befejeződött, így Oroszlány környékén jelenleg a korábban múvelt bányákhoz kapcsolódó rekultiváció van folyamatban. Jelenleg a Mátrai Erőmü (ME) a legnagyobb magyarországi szénerőmü ${ }^{3}$, illetve nagyobb mértékủ szénbányászat a hozzá kapcsolódó visontai külszíni fejtésen is folyik. A European Commission Joint Research Center (EC JRC, 2018) elöre-

\footnotetext{
${ }^{1}$ Kötelezettségvállalás az üvegházhatást okozó gázok kibocsátásának 2020-ig legalább 20\%kal történő csökkentésére az 1990-es szintekhez képest, a megújuló energiaforrások 20\%-os arányának kötelező előírása az EU számára, beleértve a bioüzemanyagok arányára vonatkozó 10\%-os célkitüzést is, végül az EU energiafelhasználásának 20\%-os csökkentése 2020-ra.

${ }^{2}$ A megújuló portfólió szabvány (RPS) keretében a szabályozó kitűzi egy adott időszakra a konkrét megújuló energiaforrásra (például: szél-, nap-, geotermikus energia) vonatkozó, kötelezően teljesítendő elvárásokat.

3 A magyar villamosenergia-rendszerben maradtak szénalapú villamosenergia-termelésre is képes kisebb blokkok (Hamburger Hungária Erőmű Kft., Bakonyi Erőmű Kft.), azonban ezek más, alternatív tüzelőanyaggal (biomassza, papírhulladék) is tudnak müködni.
} 
jelzése szerint 2030-ra a szénágazatban foglalkoztatottak száma elenyésző lesz (a VÉRT rekultivációjának befejeződése és az ME meglévő blokkjainak leállása miatt). A szénbányászat csak kisebb léptékben marad fenn: a lakosság számára fütőanyagként, illetve egyéb innovatív ipari felhasználások esetében (Fikkers, 2013; Pettinau et al., 2014; Kiss et al., 2016).

Energetikai szabályozási szempontból a magyarországi szénbányászat és szénipar helyzete leginkább abban a - jogi és társadalomtudományi keretek között újszerünek ható - megközelítésben értékelhető legjobban, amelyet a komplex rendszerek jelentenek. A szénipar helyzete ebben a megközelítésben a támogató és a megszorító hatások kölcsönhatásában az utóbbi felé mozdult el, ahol a szénipari szerkezetátalakítási támogatás sorsa és jogi természete, a Paks II kiemelt projekt és az ezekkel kapcsolatos jogi-szabályozási változások mellett a megújulók határozzák meg a szénipar helyzetét.

Habár ideiglenesen a meglévő szénalapú erőművek piaci lendületet tudtak nyerni a különböző országokban (lásd a német atomerőművek 2011 utáni átmeneti leállítása, majd fokozatos kivezetése), az európai szénbányászatot alaposan átalakítják a németországi energiapolitikai döntések. Ezek közül a legmélyrehatóbb a német kormány által felállított szénbizottság 2019. január 25-én elfogadott terve a német szénerőművek 2038-ig történő teljes kivezetéséről. Ehhez kapcsolódóan 2019. február 4-én a német villamosenergia-rendszert irányító négy cég publikálta a 2030-ig szóló hálózatfejlesztési tervének első változatát (50Hertz et al., 2019). A tervek megvalósulása az 1958 óta kiemelt kormányzati figyelmet kapó (Frondel et al., 2007) német szénalapú villamosenergia-termelés befejezését jelenti, miközben a megújuló energiaforrások áramtermelési részaránya 2030-ig 65\%-ra emelkedik, valamint 2022 végéig megtörténik a német atomerőmüvek bezárása. A német egységes energiapolitikai megközelítést mutatja, hogy a konkrét energiapolitikai döntések által okozott nehézségek és potenciális negatív hatások (áramár-növekedés; barnaszenes régiók szerkezetátalakítása; ellátásbiztonsági kockázatok; jelentős beruházási többletigény) ellenére folytatja a klímacélok EU-s elvárásoknál erőltetettebb teljesítését.

A német példa gyors követése azonban a közép-európai országokban nem várható. A hagyományosan szénre támaszkodó régiós országok energiamixének átstrukturálása óvatosan halad a magas társadalmi költségek miatt (Kissfazekas, 2015; Jonek-Kowalska, 2017; Popa-Predeanu, 2018).

\section{MAGYARORSZÁGI SZABÁLYOZÁSI PRIORITÁSOK: MEGÚJULÓK ÉS A NUKLEÁRIS ENERGIA}

A szabályozás kérdései az energiamix részeként értelmezhetők a szénipar energiapolitikai megközelítésében. Az energiamix általában, tiszta piaci szempontból természetesen elsősorban a technológia, energiaforrás és piaci kondíciók függvé- 
nye. Az energiamix kérdése azonban már csupán a szociális megfontolások miatt sem redukálható pusztán gazdasági-pénzügyi, illetve müszaki szempontokra. Az energia ma már olyan társadalmilag elvárt alapszükséglet, amelynek rendelkezésre kell állnia, hasonlóan a kenyérhez vagy a közoktatáshoz, nem véletlen, hogy az energiaár (lásd rezsicsökkentés) vagy az ellátás biztonsága a szakpolitikák közül kiemelkedve is elsősorban politikai kérdés. Az energiaszektor a piaci-kontraktuális kapcsolódásoktól eltérített szektor. Egy, a teljesen piacias, magánérdekeken alapuló viszonyoktól nagymértékben eltérített iparágban, ahol a közérdek megjelenése erőteljes, minden kérdés - így az energiamix is - rögtön jogi, szabályozási kérdés is. Fontosnak tartjuk megjegyezni, hogy mint ilyen, nem is pusztán egy jogalkotói, jogi természetü (de lege ferenda) döntés tárgya, amely különböző jogszabályokban, törvénymódosításokban, kormányhatározatokban, közigazgatási határozatokban, állami támogatási döntésekben, sémákban, netán tilalmakban kétségkívül különféle jogi formát ölt majd magára. Az energiamix mint szabályozási kérdés ma már sokkal inkább mint komplex rendszer jelentkezik, és ekként értelmezhető helyesen. Az energiamix részét jelentő szénipari viszonyrendszer jogi-szabályozási környezete is így, komplex rendszerként érthető meg a maga dinamizmusában, ahol a szabályozás negatív és pozitív irányú tendenciái komplex, rendszerszintü együtthatásukban jelölik ki az aktuális jogalkotói fókuszt.

Egy rendszer komplex, ha olyan világos függőségek vannak az egyes elemek között, amelyek elkerülhetetlenek, így ha egy elemet eltávolítunk, a rendszer viselkedése megváltozik, méghozzá az eltávolított elem súlyát jóval meghaladó mértékben (Watkins-Freeman, 2008). A komplex rendszerek sosem lineárisak, elemeik sosem függetlenek, és ellenállnak a redukcionizmusra tett minden kísérletnek. Az energiamix szempontrendszere, függőségeinek rendszere pontosan ilyen komplex rendszer. Az egyes azonosított területek természete (viselkedése) és kölcsönhatása pontosan a komplex hálózatok törvényei szerinti, és ezeket a kölcsönhatásokat, viszonyokat és függőségeket aztán e komplex rendszer részét képező szabályozás maga képezi le a jog nyelvére.

Ami ebből a komplex rendszerből közelebbről a szabályozási-jogi függőségek alrendszerét illeti a szénipar és az energiamix kapcsolata szempontjából, az a hazai jogalkotók kétirányú, ennek megfelelően egymással is ellentétes hatású tevékenységét eredményezi. Egyrészt a nukleáris energiával (Paks II), valamint a megújulókkal kapcsolatos jogi-szabályozási megfontolások mint a szénipar szempontjából negatórius (megszorító, negatív) szabályozási hatások határolják le a szénalapú energiatermelés lehetőségét, ezáltal meghatározva a szénipar szabályozási-jogi mozgásterét. Magyarország beruházási támogatást nyújt ahhoz, hogy két új reaktor épüljön a paksi telephelyen. Az elfogadott ütemterv szerint az egyenként 1200 MW-os reaktorok 2025 és 2026 során történő üzembe helyezése a cél. A közvetlen kiváltó ok a paksi telephelyen jelenleg müködö, az 1980-as években készült és jelenleg Magyarország belföldi villamosenergia-termelésének mintegy 
50\%-át biztosító négy reaktor felváltása. Magyarország véleménye szerint Paks II megépítésére szükség van a leépítésre kerülő kapacitások helyettesítése és az új termelési kapacitások iránti igények kielégítése miatt (REKK, 2013; Aszódi et al., 2014). Az Európai Bizottság maga is megvizsgálta Paks II-t tiltott állami támogatás szempontjából, és 2017. márciusban le is zárta a vonatkozó vizsgálatát, meghozva az azt jóváhagyó, ám jelentős kötelezettségeket előíró határozatát (EC, 2017). Nagyon fontos látni, hogy a jóváhagyó bizottsági határozat feltételes jóváhagyást jelent csupán: amennyiben új, nem vizsgált körülmények merülnek fel a beruházás kapcsán, vagy olyan változások állnak be a körülményekben, amelyekkel a Bizottság a vizsgálatakor még nem számolt (például az új megújuló támogatási rendszer bevezetésének csúszása), akkor ezek felpattinthatják a már egyszer lezárt eljárást.

A megújulók tekintetében az új Megújuló Támogatási Rendszer (METÁR) határolja le a mozgásteret, ami valójában egy csomag: a villamosenergia-kódex (Vet. ${ }^{4}$ ) módosítása, a kötelezö átvételi rendelet (389/2007) módosítása, végül egy új kormányrendelet a METÁR részletszabályairól. A régi kötelező átvételi (KÁT) rendszer mára lezárult, a 81/2018. (IV. 20.) Korm. rendelet zárta le, a 2020-as évre vonatkozó METÁR pályázati kiírás 2019. november 4-én került kiírásra5. A 256/2018. (XII. 18.) Korm. rendelet alapján változtak a részletszabályok is, illetve a 299/2017. (X. 17.) Korm. rendelet 2018. április 21-én hatályba lépett 18. § (7) bekezdése alapján a kötelező átvételre (METÁR KÁT) irányuló új kérelem jelenleg úgy nyújtható be, hogy - tekintettel a kimerített éves kvótára - a befogadott és kellően dokumentált projekt várakozási sorszámot kap, tehát sorban áll.

A sok bizonytalanság ellenére szabályozási-jogi oldalról a megújulók támogatása a jelenlegi szabályozási környezetben - hasonlóan a nukleáris energiaforrásból termelt villamos energiához - lényegesen eltéríti az energiamixet, leszükítve a szénalapú villamosenergia-termelés, illetve tágabban a szénipar mozgásterét. A támogatásokkal eltérített piaci-beruházói kedv, valamint az eltérített árak önmagukban is a konvencionális energiaforrások felhasználása ellen hatnak, ez a szénipar mellett a Magyarországon hagyományosan meghatározó nagy gáztüzelésű erőmüvek (Dunamenti, Budapesti, AES Tisza) sorsa szempontjából is jól érzékelhető, ami ezen konvencionális erőforrásokkal üzemelő erőmüvek rendszerszintủ szolgáltatásokban betöltött kitüntetett szerepe miatt sem elhanyagolható. Az eltérített beruházói kedv és árszínvonal mellett azonban a jogalkotó általi eltérítettség azért is negatív hatású a konvencionális energiaforrások felhasználására, mert a hazai energiaigény véges; egy ilyen korlátozott piacon, amit a hazai energiafelhasználás jelent, egy ponton túl a szén, földgáz és lignit egyszerủen szükségtelen a nukleáris és megújuló energia beépített kapacitásának növekedé-

${ }^{4}$ Vet.: a villamos energiáról szóló 2007. évi LXXXVI. törvény.

${ }^{5}$ A cikk leadásakor - 2020. január - eredményhirdetés még nem történt. 
se miatt. A paksi bővítés tervezett kapacitásnövekedése ismert, ám a megújulók tekintetében is egy $2000 \mathrm{MW}$-os beépítettkapacitás-növekedéssel lehet a kiadott engedélyek alapján számolni, annak ellenére, hogy számos (még KÁT-os) projekt várhatóan nem valósul meg. Ezek mind szükítik a hazai primer szén, lignit, földgáz iránti szükségletet, és lényegében végzetesen hatnak az ezen energiaforrások elsődleges felhasználói piacára: az ezeket az energiaforrásokat hasznosító erőmüvekre.

\section{A SZÉNIPARHOZ KAPCSOLÓDÓ TÁMOGATÁSOK KIÜRESÍTÉSE: A SZÉNFILLÉR ESETE}

A szénipart érintő pozitív jogalkotói hatás is megfigyelhető a szabályozás komplex rendszerében. A széniparhoz kapcsolódó támogatási rendszer, ami szemben az előző - negatórius - iránnyal támogató (életben tartó) szabályozást jelent, vagy helyesebben jelentett. Ennek az alapja nem egy nemzeti szintủ szabályozás, hanem egy EU-határozat, mely rögzíti, hogy a versenyképtelenül üzemelö szénbányák nem tarthatók fenn. A bányabezárások következményeinek enyhítésére a tagállamok azonban jóváhagyott állami támogatást nyújthatnak, ehhez azonban mind a bevételek, mind a ráfordítások indokoltságának vizsgálatára szükség volt. Érthető módon, hiszen a tiltott állami támogatás (illegal state aid) az Európai Unió jogának egyik sarokpontja, ahol csak jól körülhatárolható kivételek lehetségesek a föszabály, a teljes tilalom alól. A főszabály az Európai Unió müködéséről szóló szerződés (EUMSZ) 107. cikkének (1) bekezdése a közös piaccal összeegyeztethetetlen tiltott állami támogatásokról. Az EU joga szerint az állami támogatás akkor hagyható jóvá, ha a kitüzött célokra korlátozódik és azokkal arányos. A legfő́bb fenntartás az állami támogatással kapcsolatban az, hogy az gyakran okoz indokolatlan torzulást az adott piacon, így az energiapiacon is. Egy adott struktúra tiltott állami támogatássá minősítésének vizsgálata során a következő szempontok relevánsak: i) a viszonzatlan előny vagy kedvezmény, ii) az állami forrás/állami betudhatóság, iii) a szelektivitás, iv) a belső piaci verseny torzulása és v) a tagállamok közötti kereskedelem érintettsége. E szabályok technológiától függetlenül alkalmazandók, a széniparnak, a megújulóknak (METÁR) vagy épp Paks II-nek nyújtott állami támogatások vizsgálatánál is az Európai Unió müködéséröl szóló szerződés (EUMSZ) 107. cikkében megfogalmazott szabály az irányadó (EUR-Lex, 2012). Az állami támogatás mint a közös piacon fennálló versenyt torzító vagy ezzel fenyegető intézkedés jelenleg a föszabály szerint összeegyeztethetetlen (incompatible) a közös piaccal. Márpedig a közös piaccal összeegyeztethetetlen támogatás nem nyújtható, és a már nyújtott állami támogatást vissza kell fizettetni a kedvezményezettekkel. Az európai integrációt életre hívó törekvések egyik mozgatórugója az államok gazdasági érdekeinek összehangolása, majd egy belső piac megteremtése volt, amelyben a gazdasági 
szereplők között kialakulhat egy torzításmentes verseny. Valamely tagállam által alkalmazott intézkedés folytán ez a verseny torzulhat, bizonyos vállalkozások elönyösebb helyzetbe kerülhetnek az adott piac többi szereplöjéhez képest. A torzító intézkedés nemcsak kifejezett előny juttatásában testesülhet meg, hanem valamely hátránytól való mentesítéssel is. Az EUMSZ állami támogatásokra vonatkozó szabályai a belső piac múködését megzavaró, illetve az Európai Unió versenypolitikáját elősegítő szabályok érvényesülését lerontó állami intézkedéseket hivatottak korlátozni.

A szénipari szerkezetátalakítási támogatás esetén az utóbbinak, tehát a ráfordítások indokoltságának vizsgálatát Magyarországon a Magyar Energetikai és Közmü-szabályozási Hivatal (MEKH) végezte el, és ez alapján tett javaslatot a miniszternek a kifizetési volumenre. Magyarország élt az állami támogatás nyújtásának lehetőségével, és a villamos energiáról szóló 2007. évi LXXXVI. törvény (Vet.) 147. §-a alapján ún. „szénipari szerkezetátalakítási támogatás” (szénfillér) formájában nyújtja azt. A támogatás szükebben hazánk utolsó mélymüvelésü szénbányájához, a Márkushegyi Bányaüzemhez kapcsolódott. Ez a bánya biztosította a VÉRT tulajdonában álló Oroszlányi Erömü müködéséhez szükséges szénforrást. A szénfillért korábban a lakossági végfelhasználók is fizették továbbhárított tételként, azonban a rezsicsökkentés néven ismert többlépcsős szabályozási intézkedéscsomag bevezetése után kizárólag a nem lakossági fogyasztói körre hárult a teher. A szénfillér mértéke legutóbbi időkig $0,05 \mathrm{Ft} / \mathrm{kWh}$ volt.

Ehhez nagyon hasonló megoldás a szintén a Vet. 147. §-ában rögzített és külön jogszabályban meghatározott személyi kör részére a villamosenergia-iparban fennálló vagy eltöltött munkaviszonnyal összefüggésben külön jogszabálynak megfelelően biztosított kedvezményes árú villamosenergia-ellátás finanszírozásához szükséges pénzügyi források köre, a „C-tarifa”. A hivatkozott külön jogszabály a 116/2007. (XII. 29.) GKM-rendelet, amely meghatározza a villamos energia kedvezményes vásárlási (egyetemes szolgáltatói) tarifája igénybevételének feltételeit. A C-tarifa forrásai:

i. a rendszerhasználó részére villamos energiát értékesítő a) egyetemes szolgáltató, b) villamosenergia-kereskedő és c) termelői engedélyes befizetési kötelezettsége a nem lakossági fogyasztó részére közvetlenül értékesített villamos energia mennyisége alapján, amely kötelezettség egyúttal továbbhárításra is kerül a nem lakossági fogyasztó rendszerhasználó felé, valamint

ii. a közvetlenül a szervezett villamosenergia-piacról vagy külföldröl villamos energiát vásárló, nem lakossági fogyasztó rendszerhasználó.

Mind a szénfillér, mind a C-tarifa a Vet. 147. § (1) b) pontján alapul, mely szerint a MAVIR (Magyar Villamosenergia-ipari Átviteli Rendszerirányító Zártkörüen Müködö Részvénytársaság) mint átviteli rendszerirányító által az e célból létrehozott elkülönített számláján kezelt, kötelező befizetésből származó pénzeszközökből kell 
biztosítani a meghatározott jogalkotói célok támogatását. A MAVIR a beszedett pénzeszközöket a Vet. alapján - immáron kúriai ítélettel is megerösítetten - külön kezeli, azok nem minősülnek a bevételének. Az említett kúriai ítélet még nem nyilvános $^{6}$, így hivatkozni sajnos nem tudjuk, azonban megállapításai meghatározók lesznek a külön kezelt pénzeszközök (szénfillér, C-tarifa) jogi természetét, valamint a közjog-magánjog kényes határát illetően is. A kúria 2018. végi ítéletében ugyanis - egy addigra már két fokon eldöntött, jogerősen lezárt pert megfordítva - kimondta, hogy az elkülönült pénzeszköz az olyan polgári jogi intézményekre érzéketlen, mint a betudás vagy a kamatfizetés. Ezzel nagy nehezen ugyan, de végre kiforrta magát e külön pénzeszközök, így a szénfillér jogi státusza is.

Azonban hiába rögzült a szénfillér jogi megítélése 2018 végére, mivel egy nagyon fontos jogalkotói változás is történt ezzel egy időben. A szénfillér csupán 2018-ig járt, így a jogalkotó a támogatást 2019-ben lényegében kivezette, akként, hogy a szénfillér szabályozói mechanizmusa változatlan maradt (így a Vet. is), azonban annak támogatási mértéke a Vet. szerint $0 \mathrm{Ft} / \mathrm{kWh}$, ahogyan azt a 2018. évi XCIX. törvény 64. $§ 24$. pontja rögzíti. A szénipar jogalkotói támogatása tehát olyan módon szünt meg, hogy a tartalma kiüresedett, ,elapadt” az összege. Tudomásunk szerint újabb esetleges állami támogatási (EU-s) jóváhagyás híján ennek jövőbeni változása nem is várható.

Az energiaszabályozás komplex rendszerében jellemző - állami támogatási elem jelenléte esetén különösen -, hogy a szabályozás és a jogalkotás tekintetében egy adott affirmatív eszközt egy másik (negatórius) igazít ki, vagy viszont. Ez sokszor indirekt, áttételes vagy egészen szofisztikált módon jelenik meg. A szénfillér testvérének, a C-tarifa adómentességének alakulása is megerősíti ezt:

1. A Vet. szerint az általános forgalmi adóról szóló 2007. évi CXXVII. törvény 71. § (1) bekezdés c) pontja szerint nem tartoznak bele az általános forgalmi adó alapjába. A személyi jövedelemadó alóli mentesség szempontjából azonban nem a Vet., hanem a személyi jövedelemadóról szóló törvény (,,Szjatv.”) az irányadó. ${ }^{7}$

2. A közteherviselés rendszerének átalakítását célzó törvénymódosításokról szóló 2009. évi LXXVII. törvény (Első Módosító Törvény) 186. § 16. pontja

${ }^{6}$ A cikk leadásakor - 2020. január - a kúriai ítélet még mindig nem nyilvános.

${ }^{7}$ Az Szjatv. 2009. december 31. napjáig hatályos 1. számú mellékletének 8.28. pontja szerint „adómentes bevételnek minősül a villamos energiáról szóló külön törvény felhatalmazása alapján kiadott külön jogszabályban meghatározott személyi körben - a villamosenergia-iparban fennálló, vagy eltöltött munkaviszonnyal összefüggésben - külön jogszabályban meghatározottak szerint vételezett villamos energiának az egyetemes szolgáltató üzletszabályzatában meghatározott általános lakossági fogyasztói áron számított értéke és az ilyen magánszemélyre vonatkozó kedvezményes villamos energiának az egyetemes szolgáltató üzletszabályzatában - külön jogszabály előírásai szerint - meghatározott ára alapján számított érték különbsége formájában nyújtott kedvezmény". 
hatályon kívül helyezte az Szjatv. 1. számú mellékletének 8.28. pontját 2010. január 1. napjával. ${ }^{8}$

3. Ezt követően az egyes törvényeknek és törvényi rendelkezéseknek a jogrendszer túlszabályozottságának megszüntetése érdekében szükséges technikai deregulációjáról szóló 2012. évi LXXVI. törvény (Második Módosító Törvény) 7. § (3) bekezdés 12. pontja hatályon kívül helyezte az Első Módosító Törvényt, a Második Módosító Törvény 92. § (10) bekezdés 7. pontja alapján 2019. január 1. napjával. A Második Módosító Törvény 1. § (1) bekezdése szerint viszont ,az e törvénnyel hatályon kívül helyezett törvény vagy törvényi rendelkezés hatályon kívül helyezése nem érinti az annak alapján e törvény hatálybalépése előtt keletkezett, megszüntetett vagy módosított jogviszonyokat, jogokat és kötelezettségeket". A Második Módosító Törvény 92. § (1) bekezdése szerint a Második Módosító Törvény egésze 2020. január 2. napján hatályát veszti.

Mindez azt eredményezi, hogy mivel sem a módosító jogszabályok, sem az alapjogszabály nem fogja tartalmazni a C-tarifa adómentességét, ezért álláspontunk szerint a C-tarifa adómentessége 2020. január 2. napját követően hatályos jogszabályi rendelkezések hiányában nem lesz alkalmazható.

\section{KONKLÚZIÓ}

A magyarországi energiapolitika a szénalapú villamosenergia-termelést rövid távon nem akadályozza. Azonban energetikai szabályozási megközelítésben a szabályozási hatásokat komplex rendszerként tekintve - a szénipari szerkezetátalakítási támogatás mechanizmusának kiüresítésével, valamint a megújulók és a kiemelt nukleáris projekt (Paks II ) térnyerésével - a magyarországi szénbányászat és szénipar helyzete az affirmatív-támogató és a negatórius-megszorító hatások kölcsönhatásában az utóbbi irányába mozdult el. Mindezt azok a jogtechnikai megoldások teszik különösen érdekessé, amelyek a szénfillér nyújtásának jogi keretét nem szüntették meg (csak az összegét vették le nullára), a szénfillér és a C-tarifa speciális (közjogias) státuszát a bíróság tisztázta, és ahol a C-tarifa adómentességét is csupán indirekt módon, dereguláció útján vezetik ki a jogrendszerből, a komplex rendszer elemeit formai, jogi-normatív oldalról változatlanul hagyva, tartalmilag azonban érvényesítve a hangsúlyeltolódást.

${ }^{8}$ Az Első Módosító Törvény 206. § (16) bekezdése szerint „2009. december 31-én hatályos 8.12. és 8.28. pontja szerinti adómentes juttatásra az említett időpontban hatályos szabályok szerint jogosultságot szerzett magánszemélyek esetében a juttatás a jogosultságot megalapozó jogviszony fennállásáig adómentes”. 


\section{IRODALOM}

50Hertz - Amprion - TenneT - TransnetBW (2019): Netzentwicklungsplan Storm 2030. https:// www.netzentwicklungsplan.de/de

Aszódi A. - Boros I. - Kovács A. (2014): A paksi atomerőmű bővítésének energiapolitikai, müszaki és gazdasági kérdései. Magyar Energetika, 21, 3, 20-29. http://magyarenergetika.hu/ wp-content/uploads/me/ME\%202014-3.pdf

EC - European Commission (2014): Energy Economic Developments in Europe. Institutional Papers 3, http://ec.europa.eu/economy_finance/publications/european_economy/2014/energyeconomic-developments-in-europe_en.htm

EC - European Commission (2017): State Aid press release. http://ec.europa.eu/competition/index_en.html

EC - European Commission (2017): Commission Decision C (2017) 1486 final. http://ec.europa.eu/ competition/state_aid/newsletter/index.html

EC JRC - European Commission Joint Research Center (2018): EU Coal Regions: Opportunities and Challenges Ahead, 2018. JRC Science for Policy Report. publications.jrc.ec.europa.eu/repository/bitstream/JRC112593/kjna29292enn.pdf

EIA U.S. - Energy Information Administration (EIA) (2018): Annual Coal Report. https://www. eia.gov/coal/annual/

EUR-Lex (2012): Az Európai Unió müködéséröl szóló szerződés egységes szerkezetbe foglalt változata. https://eur-lex.europa.eu/legal-content/HU/TXT/?uri=celex\%3A12012E\%2FTXT

Eurostat (2019): Energy Data Tables, 2006-2017. https://ec.europa.eu/eurostat/web/energy/data/ main-tables

Fikkers, A. (2013): Coal Resources, Production and Use In Established Markets. In: Osborne, D.: The Coal Handbook: Towards Cleaner Production, Vol. 2 (Woodhead Publishing Series in Energy) 105-117.

Frondel, M. - Kambeck, R. - Schmidt, C. M. (2007): Hard Coal Subsidies: A Never-Ending Story? Energy Policy, 35, 7, 3807-3814. https://www.econstor.eu/bitstream/10419/18604/1/ DP_06_053.pdf

Haftendorn, C. - Kemfert, C. - Holz, F. (2012): What about Coal? Interactions between Climate Policies and the Global Steam Coal Market until 2030. Energy Policy, 48, 274-283. DOI: 10.1016/j.enpol.2012.05.032, https://bit.ly/37ZuI3C

Herczeg A. - Tóth M. (2019): A magyarországi szénbányászat helyzete a megújuló energiatermelés térnyerésének tükrében. XXI. Bányászati, Kohászati és Földtani Konferencia, Nagybánya (Baia Mare), 2019. május 9-12., 40-44. http://magyarenergetika.hu/wp-content/uploads/2019/04/allasfoglalas_IDT_2.pdf

IEA International Energy Agency (2018): World Energy Outlook 2018. https://webstore.iea.org/ renewables-information-2018

Jonek-Kowalska, I. (2017): Coal Mining in Central-East Europe in Perspective of Industrial Risk. Oeconomia Copernicana, 8, 1, 131-142. DOI: 10.24136/oc.v8i1.9, https://bit.ly/2RaCroL

Kiss V. M. - Hetesi Zs. - Kiss T. (2016): Issues and Solutions Relating to Hungary's Electricity System. Energy, 116, 329-340. DOI: 10.1016/j.energy.2016.09.121, https://vtk.uni-nke.hu/document/vtk-uni-nke-hu/issues-and-solutions-original.original.pdf

Kissfazekas, K. (2015): Relationships between Politics, Cities and Architecture Based on the Examples of two Hungarian New Towns. Cities, 48, 99-108. DOI: 10.1016/j.cities.2015.06.007, https://bit.ly/3a2TD8e

Miller, B. G. (2017): Coal as a Fuel. In: Miller, B. G: Clean Coal Engineering Technology. $2^{\text {nd }}$ ed. Butterworth-Heinemann, 61-104. 
NFM (2011): National Energy Strategy 2030. Ministry of National Development, Budapest, Hungary, http://2010-2014.kormany.hu/en/ministry-of-national-development/news/nationalenergy-strategy-2030-published

Nielsen, H. - Warde, P. - Kander, A. (2018): East versus West: Energy Intensity in Coal-rich Europe, 1800-2000. Energy Policy, 122, 75-83. DOI: 10.1016/j.enpol.2018.07.006, https:// www.ehs.org.uk/dotAsset/c00ae60d-6536-408c-afea-21f5a7cb1243.pdf

Pettinau, A. - Dobó Zs. - Köntös Z. et al. (2014): Experimental Characterization of a High Sulfur Hungarian Brown Coal for Its Potential Industrial Applications. Fuel Processing Technology, 122, 1-11. DOI: 10.1016/j.fuproc.2014.01.018, https://bit.ly/2tOkAfw

Popa, M. E. - Predeanu, G. (2018): Coals of Romania: Geology, Petrology and Use. International Journal of Coal Geology, 200, 103-122. DOI: 10.1016/j.coal.2018.10.011, https://bit.ly/2FELAkf

REKK (2013): Atomerőmüvi beruházások üzleti modelljei és várható megtérülésük. Műhelytanulmány. Budapest, https://rekk.hu/elemzes/125/atomeromuvi_beruhazasok_megterulese

Watkins, N. W. - Freeman, M. P. (2008): Geoscience. Natural Complexity. Science, 320, 323-324. DOI: 10.1126/science.1151611, https://www.academia.edu/19728598/Natural_Complexity 